\title{
Effects of aluminum on nucleoli in root tip cells and selected physiological and biochemical characters in Allium cepa var. agrogarum L
}

\author{
Rong Qin', Yunqiu Jiao', Shanshan Zhang', Wusheng Jiang², Donghua Liu*
}

\begin{abstract}
Background: Increased Al concentration causes reduction of mitotic activity, induction of nucleolar alteration, increase of the production of ROS and alteration of several antioxidant enzyme activities in plant cells. Allium cepa is an excellent plant and a useful biomarker for environmental monitoring. Limited information is available about the effects of Al on nucleoli, antioxidant enzyme system, contents of MDA and soluble protein in A. cepa. Therefore, we carried out the investigation in order to better understand the effects of Al on the growth, nucleoli in root tip cells and selected physiological and biochemical characters.

Results: The results showed that the root growth exposed to $50 \mu \mathrm{M} \mathrm{Al}$ was inhibited significantly. $50 \mu \mathrm{M} \mathrm{Al}$ could induce some particles of argyrophilic proteins scattered in the nuclei and extruded from the nucleoli into the cytoplasm. The nucleolus did not disaggregate normally and still remained its characteristic structure during metaphase. Nucleolar reconstruction was inhibited. $50 \mu \mathrm{M} \mathrm{Al}$ induced high activities of SOD and POD in leaves and roots significantly $(P<0.05)$ when compared with control, whereas the level of CAT was low significantly $(P<$ 0.05). At $50 \mu \mathrm{M}$ Al the content of MDA in leaves was high significantly $(P<0.05)$ at $9^{\text {th }}$ day and in roots increased $(P<0.05)$ with prolonging the treatment time during 6-12 days. The soluble protein content in leaves treated with $50 \mu \mathrm{M} \mathrm{Al}$ was high significantly $(P<0.05)$ at $6^{\text {th }}$ day and increased with prolonging the treatment time.

Conclusions: We suggest that variations in nucleoli and the alterations of antioxidant enzyme activities, MDA and soluble protein contents in Allium cepa can serve as useful biomarkers, which can provide valuable information for monitoring and forecasting effects of exposure to $\mathrm{Al}$ in real scenarios conditions. Among the antioxidant enzymes SOD and POD appear to play a key role in the antioxidant defense mechanism under Al toxicity condition. Data from MDA concentration show that Al indirectly produces superoxide radicals, resulting in increased lipid peroxidative products and oxidative stress.
\end{abstract}

\section{Background}

Aluminum $(\mathrm{Al})$ is the third most abundant element making up more than $8 \%$ of the earth's crust [1]. It is well known that $\mathrm{Al}$ is one of the most important factors limiting normal plant growth in acid soils. Al toxicity is manifested primarily by inhibition of root growth [2]. The root meristem is considered as one of the main sites of $\mathrm{Al}$ toxicity [3]. It is well demonstrated that $\mathrm{Al}$ is toxic to many plants at micromolar concentrations, affecting primarily the normal functioning of roots within minutes or hours of exposure of roots to $\mathrm{Al}$ [4].

\footnotetext{
* Correspondence: donghua@mail.zlnet.com.cn

${ }^{1}$ College of Life Sciences, Tianjin Normal University, Tianjin 300387, China

Full list of author information is available at the end of the article
}

Generation of reactive oxygen species (ROS) has been identified as an inevitable process of normal aerobic metabolism in plants and the four major types of ROS are singlet oxygen $\left({ }^{1} \mathrm{O}_{2}\right)$, superoxide $\left(\mathrm{O}_{2}^{-}\right)$, hydrogen peroxide $\left(\mathrm{H}_{2} \mathrm{O}_{2}\right)$ and hydroxyl radical $\left(\mathrm{OH}^{-}\right)$[5]. ROS can damage biological molecules including DNA, RNA, protein and lipid by inducing peroxidation [6]. The results from some investigations have shown that $\mathrm{Al}$ stress can increase the production of ROS, and activate several antioxidant enzymes in plant cells [7], suggesting that $\mathrm{Al}$ stress might induce cell death in plants through ROS-activated programmed cell death [8]. There are protective enzymatic and non-enzymatic mechanisms to scavenge ROS and alleviate their deleterious effects in
C Biomed Central 
plants [9]. To resist oxidative stress, plants can induce a series of detoxification reactions catalyzed by antioxidant enzymes, including low-molecular mass antioxidants (ascorbic acid, glutathione and carotenoids) as well as CAT(EC 1.11.1.6), SOD (EC 1.15.1.1) and POD (EC 1.11.1.7) [10]. Lipid peroxidation occurs in plants as a consequence of high ROS level when excessive ROS can not be scavenged immediately and effectively, and finally resulting in the disruption of plant growth and development [11]. Malondialdehyde (MDA) is one of the ultimate products as a result of lipid peroxidation damage and its concentration is related to the degree of membrane lipid peroxidation [12]. Therefore antioxidant enzyme activities and MDA content often serve as important physiological indicators to research the resistant abilities of plants under stress conditions. Proteins play an important role in metabolism. There are several reports related to the change of soluble protein content under treatment with $\mathrm{Al}$ [13].

Allium cepa is well known and commonly used in many laboratories because $A$. cepa is an excellent plant and a useful biomarker for environmental monitoring, with many advantages such as low cost, a large number of roots, short test time, ease of storage and handling, large cells with excellent chromosome conditions, and ease of observing abnormal phenomena of chromosomes, nuclei, and nucleoli affected during mitosis [14]. Limited information is available about the effects of $\mathrm{Al}$ on nucleolus and antioxidant enzyme system and contents of MDA and soluble protein in A. cepa. For the present investigation, the effects of $\mathrm{Al}$ on root growth, nucleoli, activities of antioxidant enzymes, MDA and soluble protein contents in $A$. cepa were investigated to provide valuable information for monitoring and forecasting effects of exposure to $\mathrm{Al}$ in real scenarios conditions.

\section{Results}

\section{Macroscopic effects of $\mathrm{Al}$ on root growth}

The effects of $\mathrm{Al}$ on root growth of Allium cepa var. agrogarum $\mathrm{L}$. varied with the concentration and treatment time (Figures 1,2). At $5 \mu \mathrm{M} \mathrm{Al}$ there was no toxic effect on root growth during the whole course treatment. Versus control there was stimulative effect on root growth $(P<0.05)$ at $0.5 \mu \mathrm{M} \mathrm{Al}$ after $48 \mathrm{~h}$ treatment. In concentration $50 \mu \mathrm{M} \mathrm{Al}$, obvious toxic effect appeared after $24 \mathrm{~h}$ treatment and $\mathrm{Al}$ inhibited root growth significantly $(P<0.05)$.

The effects of $\mathrm{Al}$ on the morphology of the roots also varied with the different concentrations of aluminum chloride in solution. At $0.5 \mu \mathrm{M}$ to $5 \mu \mathrm{M} \mathrm{Al}$, the morphology of the roots was more or less normal during the whole treatment $(3 \mathrm{~d})$. At $50 \mu \mathrm{M} \mathrm{Al}$, the root tips were stunted and bent in various directions after $24 \mathrm{~h}$ treatment (Figure 1).

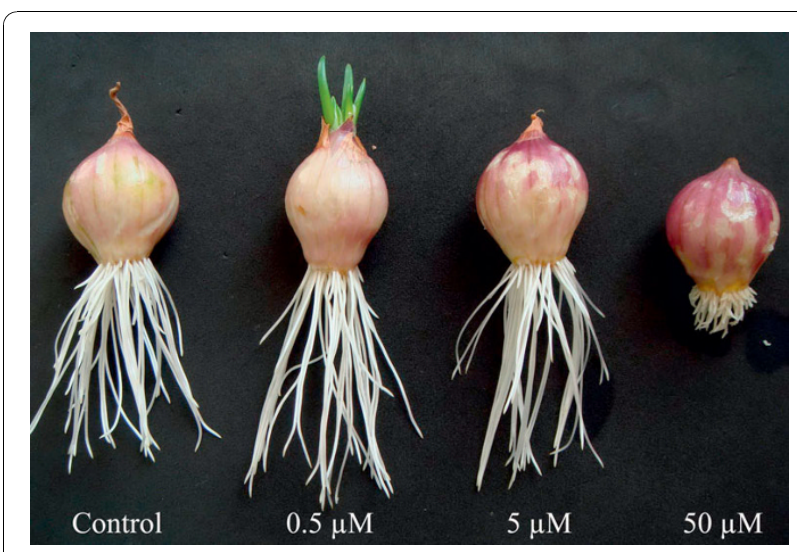

Figure 1 Effects of different concentrations of Al on root growth of Allium cepa var. agrogarum L. (72 h).

\section{Microscopic effects of Al on root tip cells}

Normally, the nucleus of Allium cepa var. agrogarum contains one nucleolus (Figure 3a-b). The toxic effects of $\mathrm{Al}$ on nucleoli varied depending on the different concentrations and the treatment time. Some tiny particulates containing the argyrophilic proteins were observed in the nucleus of the root tips exposed to $0.5 \mu \mathrm{M} \mathrm{Al}$ for $24 \mathrm{~h}$ (Figure 3c). More particulates were accumulated in it with increasing $\mathrm{Al}$ concentration and prolonging treatment time, for example, at $5 \mu \mathrm{M} \mathrm{Al}, 48 \mathrm{~h}$ (Figure $3 \mathrm{~d})$. At high concentration of $\mathrm{Al}(50 \mu \mathrm{M})$, the effects were mainly on the nucleoli. The phenomenon was noted that some particulates containing the argyrophilic proteins were extruded from the nucleus into the cytoplasm in the group treated with $50 \mu \mathrm{M} \mathrm{Al}$ for $24 \mathrm{~h}$ (Figure $3 \mathrm{e}-\mathrm{f}$ ). The nucleolar materials accumulated in the cytoplasm gradually increased with prolonging the

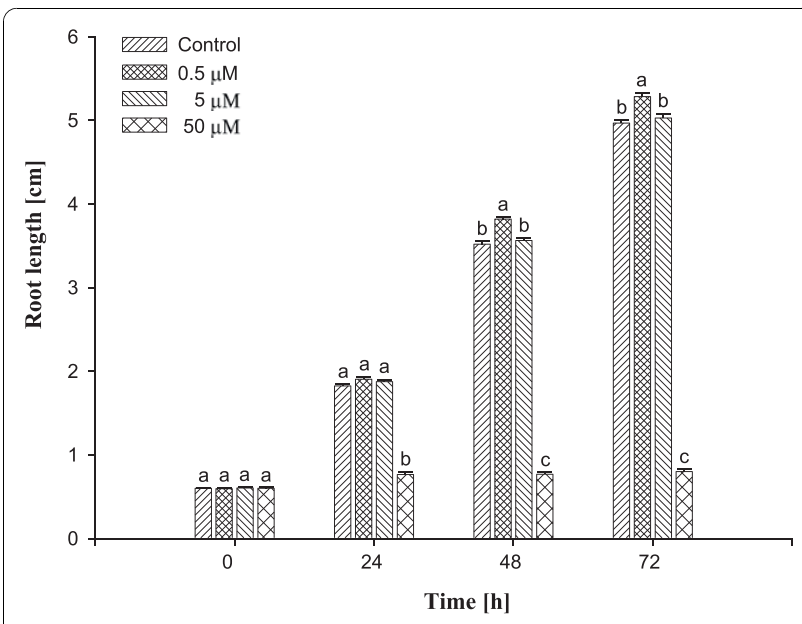

Figure 2 Effects of different concentrations of Al on root length of Allium cepa var. agrogarum L. Values with different letters differ significantly from each other $(n=25, P<0.05)$. 


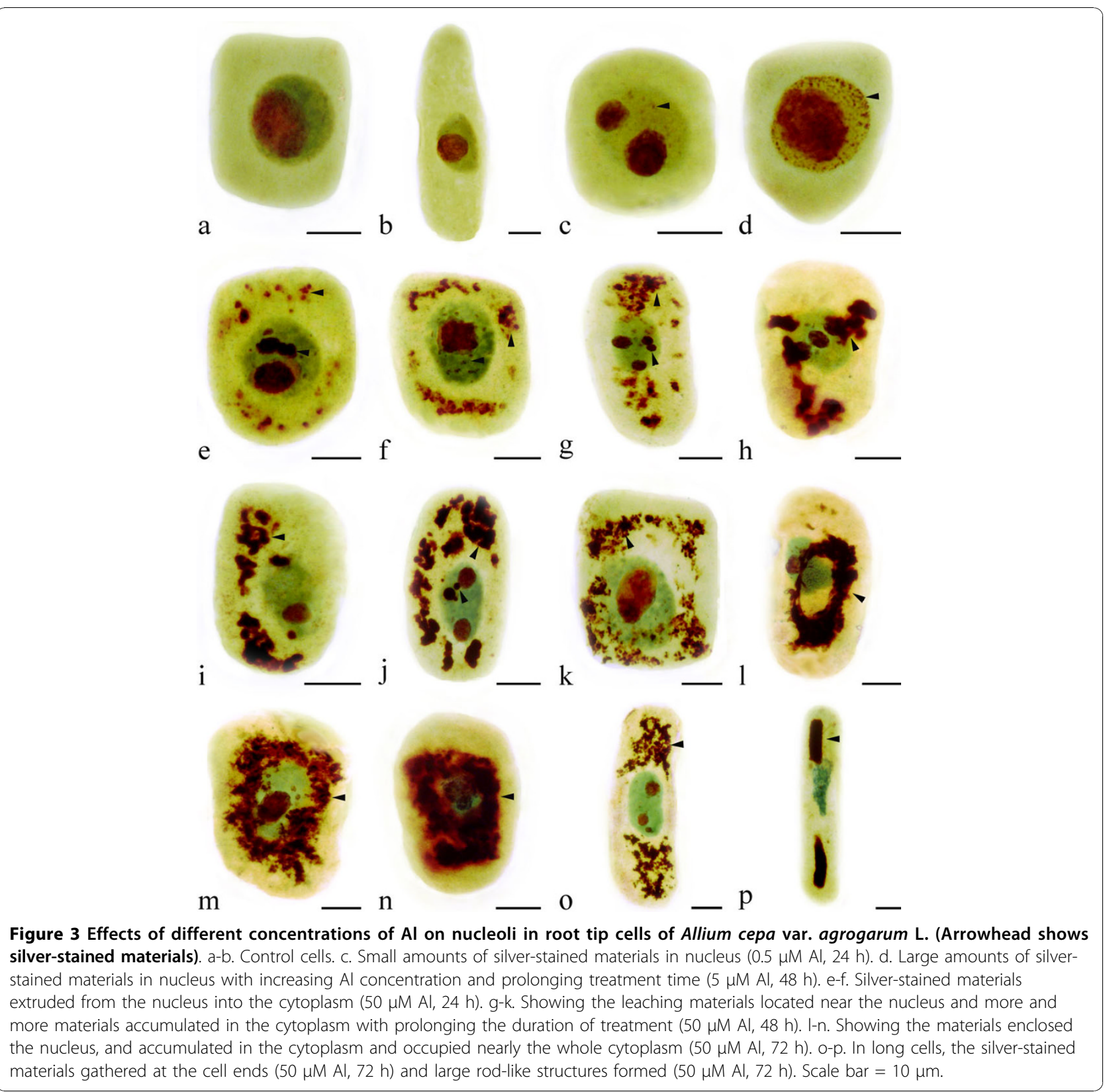

duration of treatment (Figure 3g-k). Figure 3g-k showed that the leaching materials were located near the nucleus. Finally, the material enclosed the nucleus and even occupied the whole cytoplasm (Figure 31-n). In long cells, the nucleolar materials were extruded from the nucleus into the cytoplasm, gathered at the cell ends (Figure 3o) and large rod-like structures were formed (Figure 3p).

The nucleolar cycle of silver-impregnated Allium cepa var. agrogarum cells was investigated by means of light microscopy. Normally, nucleoli in interphase nuclei impregnated with silver show strong staining. With progressing prophase decondensed chromatin fibers were around the nucleoli (Figure 4a-d). During prometaphase-metaphase, the nucleoli appeared small in size (Figure 4e), disappeared in their characteristic structures and Nucleolar Organizing Regions (NORs) were localized on chromosomes (Figure 4f). At anaphase, NORs migrated with the chromosomes to the poles (Figure $4 \mathrm{~g}$ ). In early telophase the size of the newly forming nucleoli around the NORs increased (Figure 4h). Finally, mitosis was completed. After the treatment with $\mathrm{Al}$, the abnormal phenomena of the nucleolar cycle during mitosis were examined in some cells. Firstly, the nucleoli did not disaggregate normally and still remained their characteristic structures during metaphase, which was 


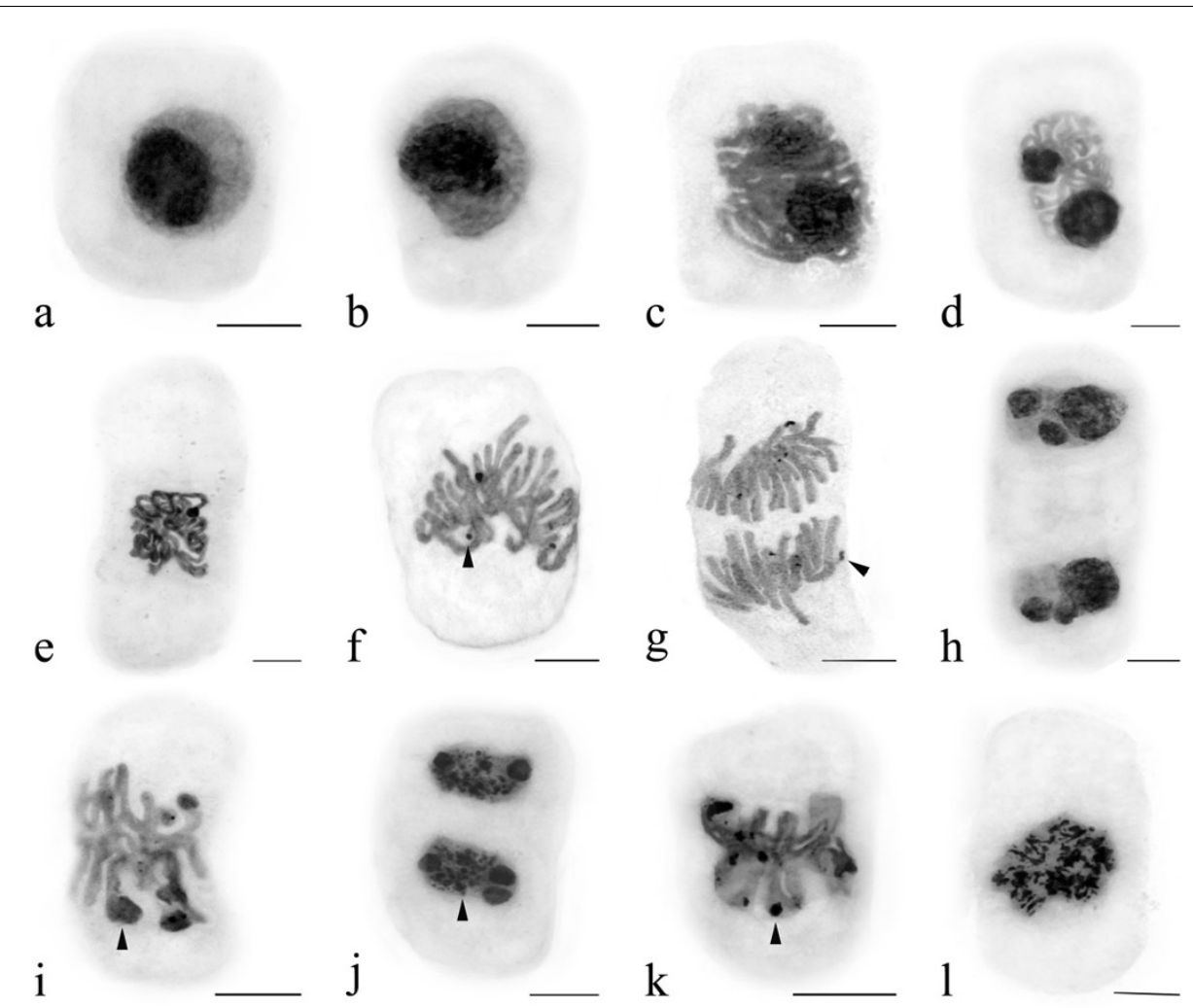

Figure 4 Effects of Al on Nucleolar Organizing Regions (NORs) in root tip cells of Allium cepa var. agrogarum L. during mitosis (Arrowhead shows NORs). a-d. Showing decondensed chromatin fibers around the nucleoli. e. Showing decreased nucleoli in size. f. Showing NORs on chromosomes. g. Showing NORs migration with the chromosomes to the poles at anaphase. h. Showing nucleoli rebuilt at early telophase. i. Nucleoli still existed after the treatment with Al during metaphase $(50 \mu \mathrm{M} \mathrm{Al}, 24 \mathrm{~h})$. j. Showing some particles of the similar silverstained materials localized in the nuclei $(50 \mu \mathrm{M} \mathrm{Al}, 48$ h). k. Showing nucleoli on chromosomes (50 $\mu \mathrm{M} \mathrm{Al}, 48 \mathrm{~h})$. I. Showing more similar silverstained materials located on sticky chromosomes (50 $\mu \mathrm{M} \mathrm{Al}, 72 \mathrm{~h}$ ). Scale bar $=10 \mu \mathrm{m}$.

referred to as persistent nucleoli (Figure 4i). Secondly, nucleolar reconstruction was inhibited, and there were still much small silver-stained particulates in the nuclei (Figure 4j). Thirdly, some particles of the silver-stained materials were still localized on chromosomes (Figure $4 \mathrm{k})$. Fourthly, there were not NORs but lots of silverstained particulates were localized on the sticky chromosomes (Figure 4l).

\section{Effects of $\mathrm{Al}$ on activities of antioxidant enzymes}

Effects of $\mathrm{Al}$ on SOD activities of Allium cepa var. agrogarum leaves and roots varied with the different concentrations of $\mathrm{Al}$ and the duration of treatment. The SOD activities in leaves exposed to $0.5 \mu \mathrm{M}-50 \mu \mathrm{M}$ Al during the whole treatment were high significantly $(P<0.05)$ when compared with control (Figure 5a). And the levels of SOD in leaves treated with $5 \mu \mathrm{M}-50 \mu \mathrm{M}$ Al were high significantly $(P<0.05)$ in comparison with the group exposed to $0.5 \mu \mathrm{M}$ Al. The trend was observed that during 3 to 9 days, the SOD activities increased with prolonging treatment time, and then decreased. The level of SOD in the leaves exposed to $50 \mu \mathrm{M} \mathrm{Al}$ was 2 times that of control on the $12^{\text {th }}$ day. The activities in roots were lower than the ones in leaves (Figure $5 \mathrm{a}, \mathrm{b})$. Figure $5 \mathrm{~d}$ showed the effects of different concentrations of $\mathrm{Al}$ on the $\mathrm{SOD}$ activities of $A$. cepa var. agrogarum roots. The levels of SOD in roots exposed to 0.5 $\mu \mathrm{M}-50 \mu \mathrm{M} \mathrm{Al}$ were high significantly $(P<0.05)$ in comparison with control. The activity of SOD in roots treated with $5 \mu \mathrm{M}$ Al was the highest and increased with prolonging the treatment time, whereas the activity at $50 \mu \mathrm{M} \mathrm{Al}$ decreased progressively.

Data from Figure 5c also showed the same trend observed in SOD that the levels of POD in leaves exposed to $0.5 \mu \mathrm{M}-50 \mu \mathrm{M} \mathrm{Al}$ were high significantly $(P<0.05)$ during the whole treatment when compared with control, except for the group exposed to $0.5 \mu \mathrm{M} \mathrm{Al}$ at $3^{\text {rd }}$ day. The activity of POD in leaves treated with 50 $\mu \mathrm{M} \mathrm{Al}$ was the highest. The activities of POD in leaves exposed to all concentrations of Al increased with prolonging duration of treatment. The POD activity in roots treated with $50 \mu \mathrm{M} \mathrm{Al}$ was noted to be high significantly $(P<0.05)$ in comparison with control and the other treatment groups (Figure $5 \mathrm{~d}$ ). $0.5 \mu \mathrm{M} \mathrm{Al}$ had no 

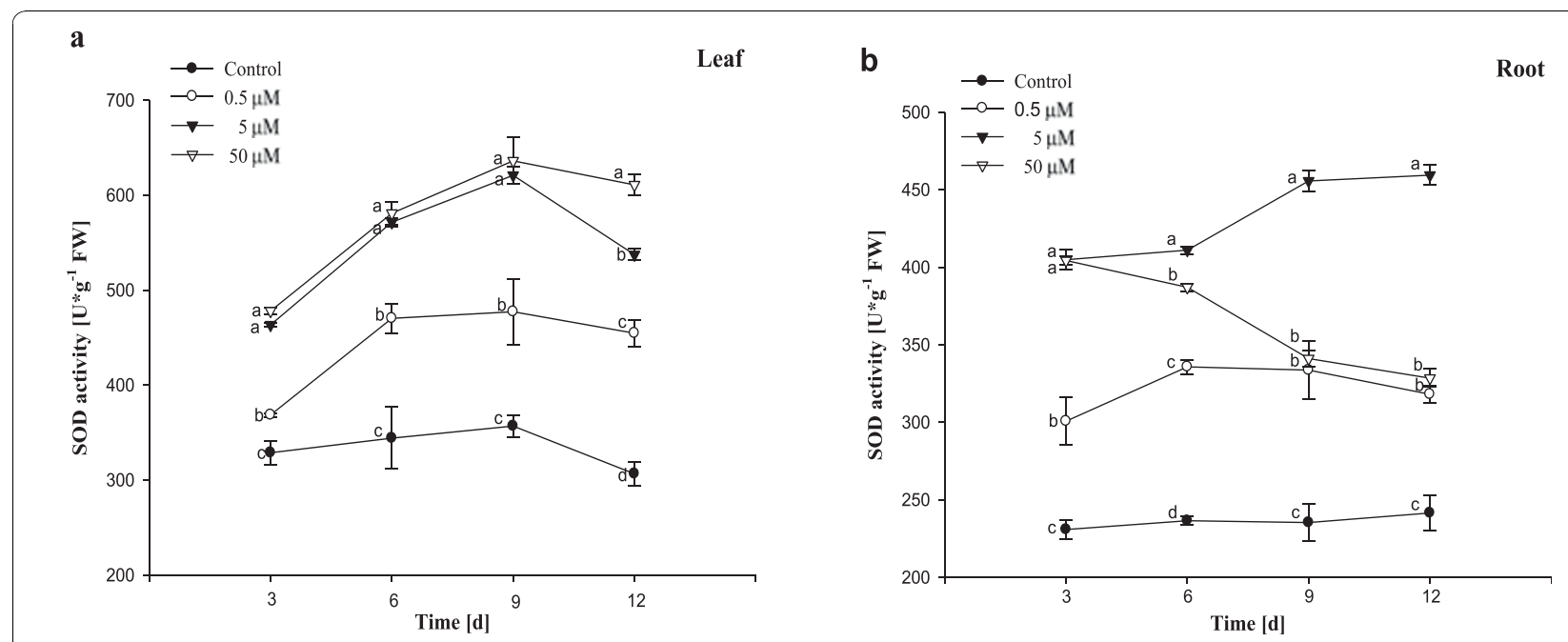

c
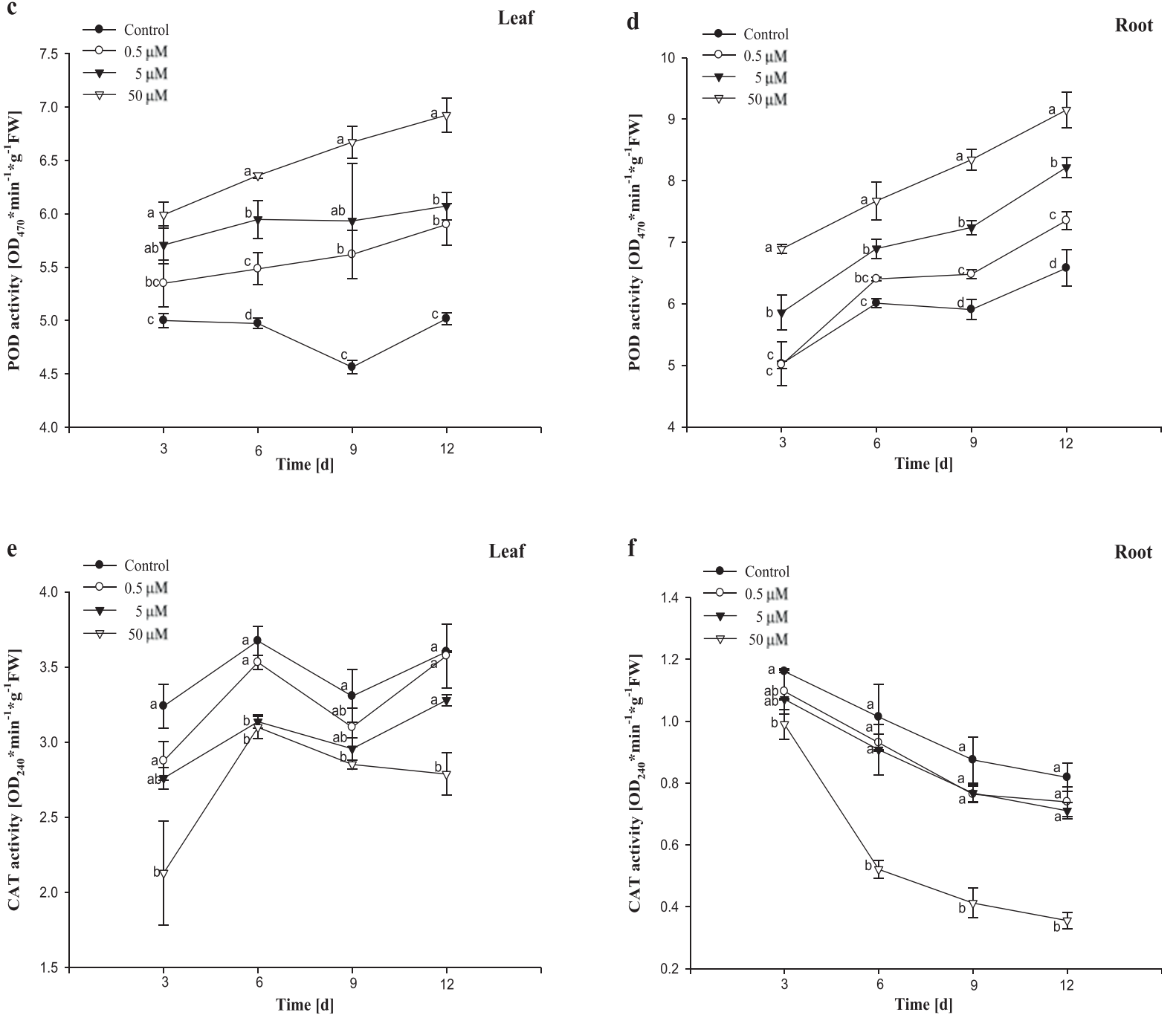

Figure 5 Effects of different concentrations of Al on the activities of three antioxidant enzymes in Allium cepa var. agrogarum L. exposed to Al stress over 12 days. a SOD in leaves, b SOD in roots, c POD in leaves, d POD in roots, e CAT in leaves, f CAT in roots. Vertical bars denote SE. Values with different letters differ significantly from each other $(P<0.05, t$-test). 
obvious effect on the POD activity in roots during 3 - 6 days when compared with control (Figure $5 \mathrm{~d}$ ). The results indicated that the activity of POD in roots increased significantly with increasing $\mathrm{Al}$ concentration and prolonging treatment time, except the group exposed to $0.5 \mu \mathrm{M} \mathrm{Al}$ during 3 to 6 days.

Information on CAT activity was given in Figure 5e and $\mathrm{f}$. The CAT activity was found to be inhibited significantly $(P<0.05)$ and to be the lowest in leaves at 50 $\mu \mathrm{M} \mathrm{Al}$ during the whole treatment when compared with control and the group exposed to $0.5 \mu \mathrm{M} \mathrm{Al}$ (Figure 5e). There was no obvious difference in the CAT activities in leaves exposed to $0.5 \mu \mathrm{M} \mathrm{Al}$ and control during the whole treatment. The activity of CAT in leaves exposed to $5 \mu \mathrm{M} \mathrm{Al}$ was only inhibited significantly $(P<0.05)$ at $6^{\text {th }}$ day. There was an inhibitory effect $(P<0.05)$ on the CAT activity in roots treated with $50 \mu \mathrm{M} \mathrm{Al}$ in comparison with control and other treated groups during the whole treatment (Figure 5f). And the other groups had no obvious effects when compared with control.

\section{Effects of Al on MDA and soluble protein contents}

The effects of $\mathrm{Al}$ on MDA concentration were presented in Figure 6. The MDA contents in leaves exposed to 0.5 $\mu \mathrm{M}-5 \mu \mathrm{M}$ Al had no obvious difference when compared with control (Figure 6a). The content in leaves treated with $50 \mu \mathrm{M} \mathrm{Al}$ was high significantly $(P<0.05)$ at $9^{\text {th }}$ day. The MDA contents in roots exposed to 50 $\mu \mathrm{M} \mathrm{Al}$ increased $(P<0.05)$ with prolonging the treatment time during 6-12 days when compared with control (Figure 6b). However, the MDA contents in roots treated with $0.5 \mu \mathrm{M}-5 \mu \mathrm{M} \mathrm{Al}$ were more or less the same as control (Figure 6b). As could be seen from
Figure 7a, the soluble protein contents in leaves exposed to $0.5 \mu \mathrm{M}-5 \mu \mathrm{M} \mathrm{Al}$ were more or less the same as control during the whole treatment time. The content in leaves treated with $50 \mu \mathrm{M} \mathrm{Al}$ was high significantly $(P<$ $0.05)$ at $6^{\text {th }}$ day and increased with prolonging the treatment time. Data from Figure $7 \mathrm{~b}$ showed that the content in roots exposed to $0.5 \mu \mathrm{M} \mathrm{Al}$ had no obvious difference when compared with control. The contents at $5 \mu \mathrm{M} \mathrm{Al}$ were high significantly $(P<0.05)$ at $3^{\text {rd }}$ day and $6^{\text {th }}$ day in comparison with control. The trend above was also observed at $50 \mu \mathrm{M} \mathrm{Al}$. However, the content was low significantly $(P<0.05)$ from $9^{\text {th }}$ day and below control.

\section{Discussion}

Root is the most sensitive and accessible part to $\mathrm{Al}$ toxicity, and root growth inhibition upon exposure to $\mathrm{Al}$ has been used extensively as one of the most distinct and earliest symptoms of Al toxicity [15]. Data from the present investigation demonstrated significant root growth inhibition in Allium cepa var. agrogarum L. seedlings exposed to $50 \mu \mathrm{M}$ Al. This investigation showed that $0.5 \mu \mathrm{M} \mathrm{Al}$ had a stimulative effect on root growth which was in agreement with the early findings [16].

Nucleolus is well known as the site of transcription of ribosomal genes and further transcript process [17], which contains a set of acidic, nonhistone proteins that bind silver ions and are selectively visualized by silver method. NORs are defined as nucleolar components containing a set of argyrophilic proteins, which are selectively stained by the silver method [18]. Proteinic carboxyls firstly combine and deoxidize certain silver
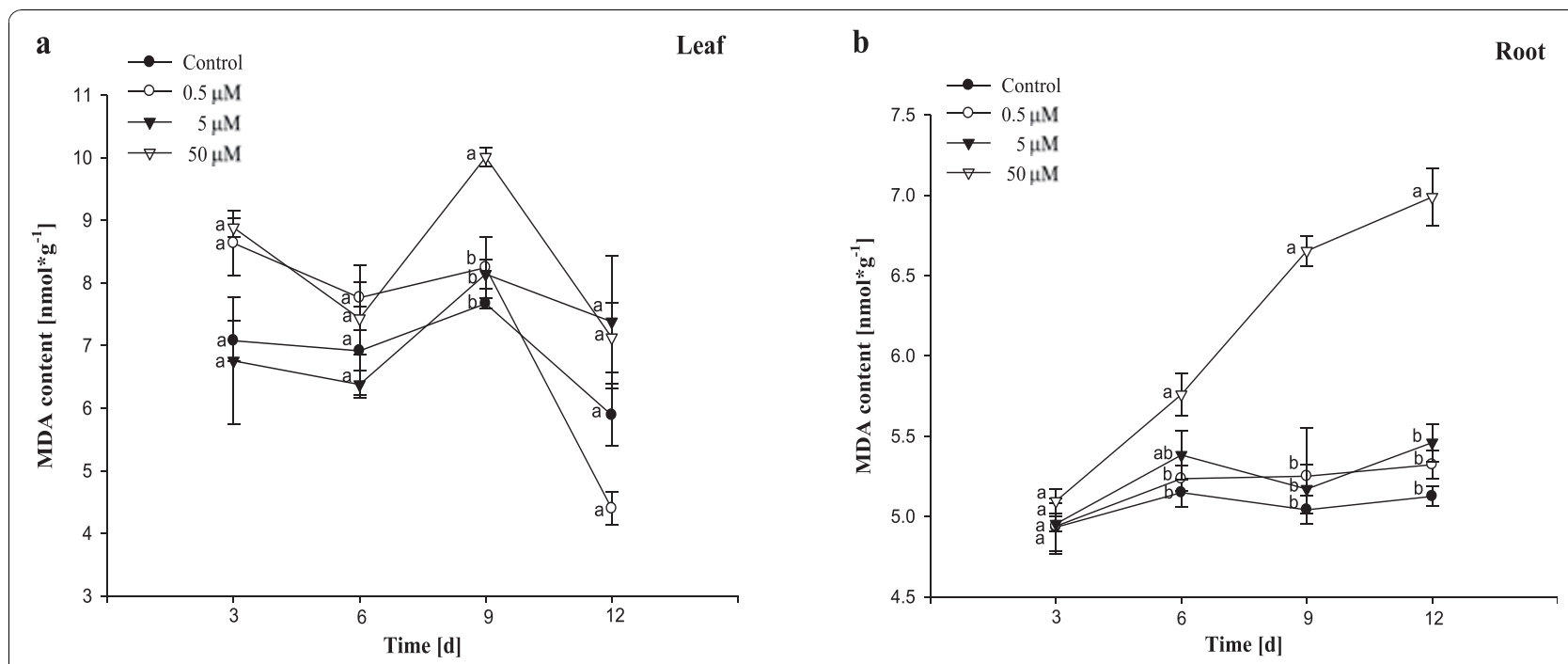

Figure 6 Effects of different concentrations of Al on MDA content in Allium cepa var. agrogarum L. exposed to Al stress over 12 days a Leaves, b Roots. Vertical bars denote SE. Values with different letters differ significantly from each other $(P<0.05, t$-test). 

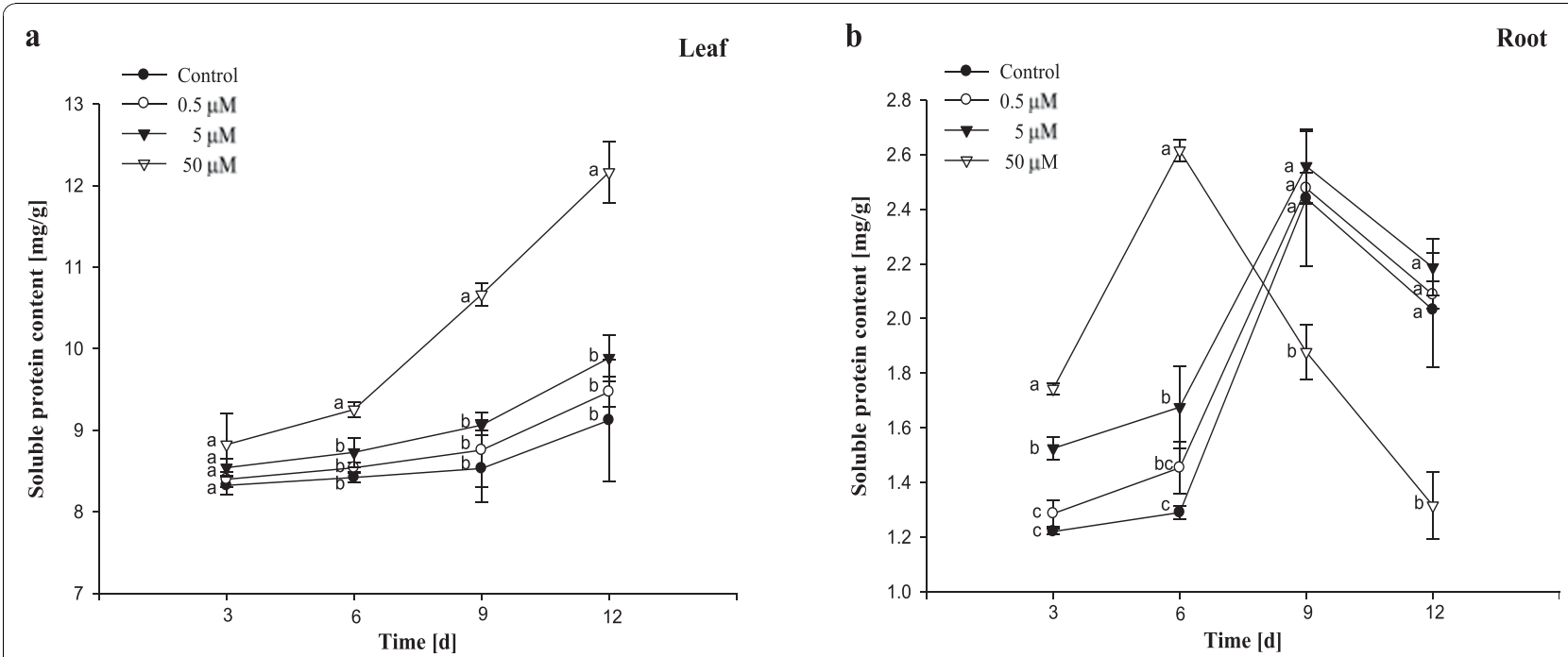

Figure 7 Effects of different concentrations of Al on soluble protein content in Allium cepa var. agrogarum L. exposed to Al stress over 12 days. a Leaves, b Roots. Vertical bars denote SE. Values with different letters differ significantly from each other $(P<0.05, t$-test).

cations $\left(\mathrm{Ag}^{+}\right)$, and then more silver cations continue to deposit at the focalization. So after silver-staining, the nucleoli can be selectively stained and the NORs can be easily identified as black dots [18].

Nucleolin is one of the main proteins in nucleolus and oxidative stress could induce the cleavage of it [19]. van der Aa et al. [20] indicated that the nuclear pore complex (NPC) was the most important channel for nuclear material. The phenomenon that the nucleolar material was extruded from the nucleus into the cytoplasm could be explained by the fact that the proteins were affected after Al treatment, causing the NPC to lose selectivity. Recent study indicated that $\mathrm{Al}$ was localized inside the nucleoli of root tip cells of $\mathrm{Al}$ sensitive maize [21].

Active NORs are associated with a subset of specific proteins and play an important role in forming nucleoli [22]. Normally, persistent nucleoli do not occur during normal mitosis. An increased number of persistent nucleoli cells increased nucleolar activity [23]. Sheldon et al. [24] found that embryonal carcinoma lines exhibited nucleolar persistence during mitotic metaphase and anaphase, indicating that rRNA synthesis continued in persistent nucleoli, which means increased biosynthetic activity and more protein production. We supposed that the phenomenon persistent nucleoli occurred in the present investigation might be an adaptive response to stress induced by $\mathrm{Al}$.

Although $\mathrm{Al}$ itself is not a transition metal and cannot catalyze redox reactions, the $\mathrm{Al}$-induced oxidative stress has been observed in many plant species [25]. It has even been suggested that Al-enhanced oxidative stress is a decisive event for inhibition of cell growth [26]. Alinduced oxidative stress and changes in cell wall properties have been suggested as the two major factors leading to Al toxicity [27]. The presence of oxygen in the cell environment can cause continuous oxidative damage to cell structure and function [28]. It is widely accepted that $\mathrm{Al}$ toxicity represents an oxidative stress in plants by inducing formation of ROS [8].

Superoxide dismutase is called the cell's first line of defense against ROS because superoxide radical is a precursor to several other highly reactive species so that control over the steady state of superoxide concentration by SOD constitutes an important protective mechanism [29]. SOD activity was affected by $\mathrm{O}_{2}{ }^{-}$concentration and increased with the increasing of $\mathrm{O}_{2}{ }^{-}$concentration [30]. Our results may be attributed to the increased production of superoxide, especially at concentrations at which root growth is strongly inhibited. The results here are consistent with the early findings $[16,25]$. The activity of SOD in roots treated with $50 \mu \mathrm{M} \mathrm{Al}$ decreased progressively with prolonging duration of treatment, which was similar to the early findings of Wang et al. [31]. This may be attributed to an inactivation of the enzyme by $\mathrm{H}_{2} \mathrm{O}_{2}$ produced in different compartments, where SOD catalyzes the disproportionation of superoxide radicals. Aravind and Prasad [32] indicated that excessive ROS could also attack SOD and decreased its activity.

Peroxidase activity increases with the increasing of $\mathrm{H}_{2} \mathrm{O}_{2}$ concentration [33] and protects cells against the destructive influence of $\mathrm{H}_{2} \mathrm{O}_{2}$ by catalysing its decomposition through oxidation of phenolic and endiolic cosubstrates [8]. The enhanced activity of anionic POD could act to confer $\mathrm{Al}$ resistance by detoxifying ROS and restricting lipid peroxidation in membrane regions [34]. In the present investigation enhancement in POD 
activity was observed, which was in agreement with the observations by Hossain et al. [35] and Wang et al. [36]. Increase in POD activity was supposed that on the one hand $\mathrm{Al}$ directly caused excessive production of $\mathrm{H}_{2} \mathrm{O}_{2}$ in seedlings and on the other hand increased $\mathrm{H}_{2} \mathrm{O}_{2}$ was due to the result that SOD dismutated more $\mathrm{O}_{2}{ }^{-}$, subsequently excessive $\mathrm{H}_{2} \mathrm{O}_{2}$ induced the over-expression of POD gene. So increased POD activity, in turn, scavenged excessive $\mathrm{H}_{2} \mathrm{O}_{2}$ and the damage was not serious.

Catalase is the most universal oxidoreductase, which scavenges $\mathrm{H}_{2} \mathrm{O}_{2}$ to $\mathrm{O}_{2}$ and $\mathrm{H}_{2} \mathrm{O}$. The major function of $\mathrm{CAT}$ is to metabolize the peroxide liberated in the peroxisome following the conversion of glycolate during photorespiration [37]. The CAT activities in leaves and roots treated with $50 \mu \mathrm{M} \mathrm{Al}$ in the present work declined whereas POD activities increased. It may be that POD plays a main role in clearing $\mathrm{H}_{2} \mathrm{O}_{2}$. Decline in CAT activity was supposed that it was due to inhibition of enzyme synthesis or a change in assembly of enzyme submits. Possibly CAT is a less efficient $\mathrm{H}_{2} \mathrm{O}_{2}$ scavenger than POD because of its low substrate affinity, and is more sensitive to high Al level than SOD and POD. Boscolo et al. [38] reported no change in CAT activity under Al toxicity in maize, while in some other plants a decline (soybean, rice) or enhancement (tobacco, wheat) of CAT activity has been found [39-41]. These results regarding CAT activity might be due to differences in the plant organs studied, the durations and concentrations of metals utilized, and the plant species.

In contrast, effects of $\mathrm{Al}$ on antioxidant enzymes are more serious in roots than in leaves, which can be explained by the fact that $\mathrm{Al}$ is taken up mostly through the root system, and accumulated high concentration in roots, only small amounts penetrate the leaves [42].

MDA formation is used as the general indicator of the extent of lipid peroxidation resulting from oxidative stress. Our results indicated that the extent of lipid peroxidation was not serious in leaves under $0.5 \mu \mathrm{M}-50$ $\mu \mathrm{M} \mathrm{Al}$ stress, suggesting that ROS was eliminated effectively as to the increase of antioxidant enzymes (SOD and POD) activities in leaves. MDA concentrations in roots exposed to $50 \mu \mathrm{M} \mathrm{Al}$ during 6-12 days increased versus control, indicating that $\mathrm{Al}$ indirectly produced ROS and there was a serious imbalance between the production of ROS and antioxidative defense, resulting in increased lipid peroxidative products and oxidative stress in roots.

In the present study, it was found that under $50 \mu \mathrm{M}$ $\mathrm{Al}$ stress, soluble protein contents in leaves increased significantly $(P<0.05)$ during 6 to 12 day treatment. The result supports the findings by Özdemir et al. [43] and Zhou et al. [44]. The high soluble protein content induced by $\mathrm{Al}$ can be explained by the following two aspects. On the one hand $\mathrm{Al}$ induces the expression of several genes and increases the synthesis of several original proteins [45]. On the other hand Al-resistance proteins are inducible by high concentration of $\mathrm{Al}$ exposure [46]. In roots exposed to $50 \mu \mathrm{M} \mathrm{Al}$ at $3^{\text {rd }}$ day and $6^{\text {th }}$ day, the soluble protein contents were high significantly $(P<0.05)$. Then it showed a decreased. We considered that during earlier period of treatment, $\mathrm{Al}$ did not injure the roots heavily and induced protein synthesis and accumulation in cells. $\mathrm{Al}$, with the stress strengthening, caused the original protein degeneration and decomposition [47] and restrained the new protein synthesis [48], which made soluble protein content decrease significantly.

\section{Conclusion}

In view of the present findings, we suggest that (1) variations in nucleoli and alterations of antioxidant enzymes and MDA and soluble protein contents in Allium cepa can serve as useful biomarkers in ecotoxicological tests with Al; (2) These biomarkers can provide valuable information for monitoring and forecasting early effects of exposure to $\mathrm{Al}$ in real scenarios conditions; (3) Al toxicity is associated with induction of oxidative stress in leaves and roots of $A$. cepa. Among the antioxidant enzymes SOD and POD appear to play a key role in the antioxidant defense mechanism and (4) MDA concentration shows that $\mathrm{Al}$ indirectly produces superoxide radicals, resulting in increased lipid peroxidative products and oxidative stress in roots.

\section{Methods}

\section{Culture condition and aluminum treatment}

Healthy and equal-sized onion cloves were chosen from Allium cepa var. agrogarum L. The bulbs had started neither shooting of green leaves nor any growth of roots. Before starting the experiment, the dry scales of the bulbs were removed. The bulbs were germinated and grown in plastic containers at $27^{\circ} \mathrm{C}$ for 3 days by dipping the base in water. Then the seedlings were grown in containers with $2 \mathrm{~L}$ Hoagland's nutrient solution ( $\mathrm{pH} 4.5$ ) adding $0.5 \mu \mathrm{M}, 5 \mu \mathrm{M}$ and $50 \mu \mathrm{M}$ Al for 12 days respectively in a greenhouse where relative humidity $(60 \%)$ and supplementary lighting (14 h photoperiod) were controlled. The Hoagland's solution consisted of $5 \mathrm{mM} \mathrm{Ca}\left(\mathrm{NO}_{3}\right)_{2}, 5 \mathrm{mM} \mathrm{KNO}_{3}, 1 \mathrm{mM}$ $\mathrm{KH}_{2} \mathrm{PO}_{4}, 50 \mu \mathrm{M} \mathrm{H}_{3} \mathrm{BO}_{3}, 1 \mathrm{mM} \mathrm{MgSO}{ }_{4}, 4.5 \mu \mathrm{M} \mathrm{MnCl}_{2}$, $3.8 \mu \mathrm{M} \mathrm{ZnSO}_{4}, 0.3 \mu \mathrm{M} \mathrm{CuSO}_{4}, 0.1 \mu \mathrm{M}\left(\mathrm{NH}_{4}\right)_{6} \mathrm{Mo}_{7} \mathrm{O}_{24}$ and $10 \mu \mathrm{M}$ FeEDTA [49]. Hoagland's nutrient solution was used for control. The solutions were aerated by pumps, which connected the containers with pump lines. In each treatment group, twenty-four treated seedlings were examined and recorded every $24 \mathrm{~h}$ for the 
morphological observation (72 h) and for examination of antioxidant enzyme activities and MDA and soluble protein contents at the end of each time interval $(3 \mathrm{~d})$. All treatments were done in six replicates. The $\mathrm{Al}$ was provided as aluminum chloride.

\section{Cytological study}

The bulbs were germinated in distilled water at $25^{\circ} \mathrm{C}$, producing roots reaching about $0.6 \mathrm{~cm}$ length. After that, they were treated in Patri dishes with different concentrations of $\mathrm{Al}$ solutions $(0.5 \mu \mathrm{M}, 5 \mu \mathrm{M}$ and $50 \mu \mathrm{M})$ for $24 \mathrm{~h}, 48 \mathrm{~h}$ and $72 \mathrm{~h}$. Distilled water was used for control experiment. The test liquids were changed regularly every $24 \mathrm{~h}$. Ten root tips in each treatment group were cut and fixed in 3 parts $95 \%$ ethanol: 2 parts acetic acid for $2 \mathrm{~h}$ and hydrolyzed in 5 parts $1 \mathrm{M}$ hydrochloric acid:3 parts $95 \%$ ethanol:2 parts $99.8 \%$ acetic acid for 4 $5 \mathrm{~min}$ at $60^{\circ} \mathrm{C}$. For the observation of changes in nucleolus, ten root tips were cut and squashed in $45 \%$ acetic acid, dried, and after 2 days stained with silver nitrate [50].

\section{Examination of antioxidant enzyme activities}

The fresh roots or leaves from each treatment were homogenized in a pestle and mortar with $0.05 \mathrm{M}$ sodium phosphate buffer ( $\mathrm{pH} 7.8)$ at the end of each time interval ( $3 \mathrm{~d}$ ) of the $\mathrm{Al}$ treatment. The homogenate was centrifuged at $10,000 \times \mathrm{g}$ for $20 \mathrm{~min}$ and the supernatant was used for analyzing SOD, POD and CAT. The above steps were carried out at $4^{\circ} \mathrm{C}$ [51].

\section{SOD assay}

The SOD activity was estimated according to the modified method of Zhang et al. [52]. The reaction mixture was made of $54 \mathrm{~mL}$ methionine, $2 \mathrm{~mL}$ nitroblue tetrazolium chloride (NBT), $2 \mathrm{~mL}$ EDTA- $\mathrm{Na}_{2}, 2 \mathrm{~mL}$ riboflavin. Appropriate quantity of enzyme extract was added to the reaction mixture. The reaction started by placing tubes below two $15 \mathrm{~W}$ fluorescent lamps for $15 \mathrm{~min}$. Reaction stopped by keeping the tubes in dark for 10 min. Absorbance was recorded at $560 \mathrm{~nm}$. One unit of SOD enzyme activity was defined as the quantity of SOD enzyme required to produce a $50 \%$ inhibition of reduction of NBT under the experimental conditions and the specific enzyme activity was expressed as units per $g$ fresh weight.

\section{POD assay}

The activity of POD was determined as described by Zhang et al. [52]. The reaction mixture in a total volume of $50 \mathrm{~mL} 0.1 \mathrm{M}$ sodium phosphate buffer ( $\mathrm{pH}$ 6.0) containing $19 \mu \mathrm{L} \mathrm{H}_{2} \mathrm{O}_{2}$ (30\%), $28 \mu \mathrm{L}$ guaiacol was prepared immediately before use. Then $1 \mathrm{~mL}$ enzyme extract was added to $3 \mathrm{~mL}$ reaction mixture. Increase in absorbance was measured at $470 \mathrm{~nm}$ at $0.5 \mathrm{~min}$ intervals up to 2 min using a UV-Vis spectrophotometer (UV-2550, Shimadzu, Kyoto, Japan). Enzyme specific activity is defined as units (one peroxidase activity unit defined as absorbance at $470 \mathrm{~nm}$ changes per minute) per $\mathrm{g}$ of fresh weight.

\section{CAT assay}

CAT activity was assayed according to the method of Zhang et al. [52]. CAT activity was determined by a UV-Vis spectrophotometer (UV-2550, Shimadzu, Kyoto, Japan) in $2.8 \mathrm{~mL}$ reaction mixture containing $1.5 \mathrm{~mL}$ $0.05 \mathrm{M}$ sodium phosphate buffer ( $\mathrm{pH} 7.8), 1 \mathrm{~mL}$ deionized water and $0.3 \mathrm{~mL} 0.1 \mathrm{M} \mathrm{H}_{2} \mathrm{O}_{2}$ prepared immediately before use, then $0.2 \mathrm{~mL}$ enzyme extract was added. The CAT activity was measured by monitoring the decrease in absorbance at $240 \mathrm{~nm}$ at $0.5 \mathrm{~min}$ intervals up to 2 min as a consequence of $\mathrm{H}_{2} \mathrm{O}_{2}$ consumption. Activity was expressed as units (one catalase activity unit defined as absorbance at $240 \mathrm{~nm}$ changes per minute) per $g$ of fresh weight.

\section{Examination of MDA content}

Level of lipid peroxidation was expressed as the content of malondialdehyde (MDA) according to Zhang et al. [52]. The fresh samples from each treatment were homogenized in $5 \mathrm{~mL}$ of $10 \%$ trichloroacetic acid (TCA) with a pestle and mortar at the end of each time interval (3 d). Homogenates were centrifuged at $4000 \times \mathrm{g}$ for 20 $\mathrm{min}$. To each $2 \mathrm{~mL}$ aliquot of the supernatant, $2 \mathrm{~mL}$ of $0.6 \% 2$-thiobarbituric acid (TBA) in 10\% TCA was added. The mixtures were heated in boiled water for 15 min and then quickly cooled in an ice bath. After centrifugation at $4000 \times \mathrm{g}$ for $10 \mathrm{~min}$, the absorbance of the supernatant was recorded at $532 \mathrm{~nm}$ and $450 \mathrm{~nm}$. Lipid peroxidation was expressed as the MDA content in nmol per $g$ of fresh weight.

\section{Measurement of soluble protein content}

Measuring soluble protein content in this investigation was carried out according to Bradford's method [53] using BSA as a standard. The fresh roots and leaves from each treatment ( 6 seedlings) were washed in distilled water, dried and put in a mortar with $5 \mathrm{~mL} 0.05$ M PBS (pH 7.8) at the end of each time interval ( $3 \mathrm{~d}$ ) of the $\mathrm{Al}$ treatment. The homogenate was centrifuged at $10,000 \times \mathrm{g}$ for $20 \mathrm{~min}$ and the supernatant was used for analyzing soluble protein content. The soluble protein content was expressed as $\mathrm{mg}$ per $\mathrm{g}$ fresh weight.

\section{Statistical analysis}

Each treatment was replicated 6 times for statistical validity. Analysis of variance of the data was done with SigmaPlot 8.0 software. For statistical analysis, one-way 
analysis of variance (ANOVA) and $t$-test were used to determine the significance at $P<0.05$.

\section{Acknowledgements}

This project was supported by the National Natural Science Foundation of China. The authors wish to express their appreciation to the reviewers for this paper.

\section{Authors' contributions}

$R Q, Y J, S Z$ and WJ carried out the present investigation, participated in sample preparation and observation and drafted the manuscript. DL conceived the study, and participated in its design and coordination and revised the manuscript. All authors read and approved the final manuscript.

\section{Author details}

'College of Life Sciences, Tianjin Normal University, Tianjin 300387, China.

${ }^{2}$ Library of Tianjin Normal University, Tianjin 300387, China.

Received: 14 June 2010 Accepted: 21 October 2010

Published: 21 October 2010

\section{References}

1. Achary VMM, Jena S, Panda KK, Panda BB: Aluminium induced oxidative stress and DNA damage in root cells of Allium cepa L. Ecotox Environ Safe 2008, 70:300-310.

2. Barceló J, Poschenrieder C: Fast root growth responses, root exudates, and internal detoxification as clues to the mechanisms of aluminium toxicity and resistance: a review. Environ Exp Bot 2002, 48:75-92.

3. De Macêdo CEC, Jan WS, Kinet JM, Lutts S: Effects of aluminium on root growth and apical root cells in rice (Oryza sativa L.) cultivars. Reliability of screening tests to detect Al resistance at the seedling stage. Acta Physiol Plant 2009, 31:1255-1262.

4. Tabaldi LA, Cargnelutti D, Gonçalves JF, Pereira LB, Castro GY, Maldaner J, Rauber R, Rossato LV, Bisognin DA, Schetinger MR, Nicoloso FT: Oxidative stress is an early symptom triggered by aluminum in Al-sensitive potato plantlets. Chemosphere 2009, 76:1402-1409.

5. Dinakar C, Abhaypratap V, Yearla SR, Raghavendra AS, Padmasree K: Importance of ROS and antioxidant system during the beneficial interactions of mitochondrial metabolism with photosynthetic carbon assimilation. Planta 2010, 231:461-474.

6. Shah K, Kumar RG, Verma A, Dubey RS: Effect of cadmium on lipid peroxidation, superoxide anion generation and activities of antioxidant enzymes in growing rice seedlings. Plant Sci 2001, 161:1135-1144.

7. Corrales I, Poschenrieder $\mathrm{CH}$, Barceló J: Boron-induced amelioration of aluminium toxicity in a monocot and a dicot species. J Plant Physiol 2008, 165:504-513.

8. Giannakoula A, Moustakas M, Syros T, Yupsanis T: Aluminum stress induces up-regulation of an efficient antioxidant system in the Al-tolerant maize line but not in the Al-sensitive line. Environ Exp Bot 2010, 67:487-494.

9. Zhang SS, Zhang HM, Qin R, Jiang WS, Liu DH: Cadmium induction of lipid peroxidation and effects on root tip cells and antioxidant enzyme activities in Vicia faba L. Ecotoxicology 2009, 18:814-823.

10. Tewari A, Singh R, Singh NK, Rai UN: Amelioration of municipal sludge by Pistia stratiotes L.: Role of antioxidant enzymes in detoxification of metals. Bioresource Technol 2008, 99:8715-8721.

11. Yang JL, Zheng SJ, He YF, Matsumoto H: Aluminium resistance requires resistance to acid stress: a case study with spinach that exudes oxalate rapidly when exposed to Al stress. J Exp Bot 2005, 56:1197-1203.

12. Bailly C, Benamar A, Corbineau F, Come D: Changes in malondialdehyde content and in superoxide dismutase, catalase and glutathione reductase activities in sunflower seed as related to deterioration during accelerated aging. Physiol Plant 2006, 97:104-110.

13. Zhang YF, Yuan CZ, Liu B, Li B, Pan L: Analysis on the influence of physiological characteristics of three northeast soybean under aluminum stress. Seed 2009, 28:21-23.

14. Liu DH, Jiang WS, Wang W, Zhai L: Evaluation of metal ion toxicity on root tip cells by the Allium test. Israel J Plant Sci 1995, 43:125-133.
15. Samuels TD, Kucukakyuz K, Magaly RZ: Al partitioning patterns and root growth as related to Al sensitivity and Al tolerance in wheat. Plant Physiol 1997, 113:527-534.

16. Liu Q, Yang JL, He LS, Li YY, Zheng SJ: Effect of aluminum on cell wall, plasma membrane, antioxidants and root elongation in triticale. Biol Plantarum 2008, 52:87-92.

17. Shaw PJ, Jordan EG: The nucleolus. Annu Rev Cell Biol 1995, 11:93-121.

18. Trerè D: AgNOR staining and quantification. Micron 2000, 2:127-131.

19. Wang KK, Jiang L, Liu K, Liu MD, Wang H, Yi YX, Yuan C, E SM, Shi YZ, Xiao XZ: Effects of heat shock protein 70 on cleavage of nucleolin induced by oxidative stress. Chin J Arterioscler 2004, 12:373-377.

20. Van der Aa MA, Mastrobattista E, Oosting R, Hennink W, Koning G, Cormmelin D: The nuclear pore complex: the gateway to successful nonviral gene delivery. Pharmaceut Res 2006, 23:447-459.

21. Amenós M, Corrales I, Poschenrieder C, Illéš P, Baluška F, Barceló J: Different Effects of Aluminum on the Actin Cytoskeleton and Brefeldin A-Sensitive Vesicle Recycling in Root Apex Cells of Two Maize Varieties Differing in Root Elongation Rate and Aluminum Tolerance. Plant Cell Physiol 2009, 50:528-540.

22. Miller OJ, Miller DA, Dev VG, Tantravahi R, Croce CM: Expression of human and suppression of mouse nucleolus organizer activity in mouse-human somatic cell hybrids. Proc Natl Acad Sci 1976, 73:4531-4535.

23. Vostrikova TV, Butorina AK: Cytogenetic responses of birch to stress factors. Biol Bull 2006, 33:185-190.

24. Sheldon S, Speers WC, Lenhman JM: Nucleolar persistence in embryonal carcinoma cells. Exp Cell Res 1981, 132:185-192.

25. Šimonovièová M, Tamás L, Huttová J, Mistrík I: Effect of aluminum on oxidative stress related enzymes activities in barley roots. Biol Plantarum 2004, 48:261-266.

26. Yamamoto Y, Kobayashi Y, Devi Sr, Rikiishi S, Matsumoto H: Aluminum toxicity is associated with mitochondrial dysfunction and the production of reactive oxygen species in plant cells. Plant Physiol 2002, 128:63-72.

27. Zheng SJ, Yang JL: Target sites of aluminum phytoxicity. Biol Plantarum 2005, 49:321-331.

28. Choudhury S, Panda Sk: Toxic effects, oxidative stress and ultrastructural changes in moss Taxithelium Nepalense (Schwaegr.) Broth. Under chromium and lead phytotoxicity. Water Air Soil Poll 2005, 167:73-90.

29. Fridovich I: Superoxide anion radical, superoxide dismutase and related matters. J Biol Chem 1997, 250:18515-18517.

30. Zheng YP, Yu HN, Liu P: The effect of aluminum on antioxidant enzyme activities of seven species of compositae plants. Guizhou Agr Sci 2009, 37:30-33.

31. Wang F, Liu P, Xu GD, Luo LL: Effects of aluminium amount in soil on the root growth of buckwheat. Guangxi Zhiwu 2006, 26:321-324.

32. Aravind P, Prasad MNV: Zinc alleviates cadmium induced oxidative stress in Ceratophyllum demersum L.: a free floating freshwater macrophyte. Plant Physiol Biochem 2003, 41:391-397.

33. Chu L, Yu XL, Li Y, Liu DY: Physiological metabolism and antioxidase activity of Parathelypteris glanduligera under Cu stress. J Biol 2008, 25(4):51-54

34. Ezaki B, Gardner RC, Ezaki Y, Matsumoto H: Expression of aluminiuminduced genes in transgenic Arabidopsis plants can ameliorate aluminum stress and/or oxidative stress. Plant Physiol 2000, 122:657-666.

35. Hossain MA, Hossain AKMZ, Kihara T, Koyama H, Hara T: AluminumInduced Lipid Peroxidation and Lignin Deposition Are Associated with an Increase in $\mathrm{H}_{2} \mathrm{O}_{2}$ Generation in Wheat Seedlings. Soil Sci Plant Nutr 2006, 51:223-230.

36. Wang F, Liu P, Xu GD, Luo LL: Effects of aluminium amount in soil on the root growth of buckwheat. Guangxi Zhiwu 2006, 26:321-324.

37. Qureshi MI, Abdin MZ, Qadir S, Iqbal M: Leadinduced oxidative stress and metabolic alterations in Cassia angustifolia Vahl. Biol Plantarum 2007, 51:121-128.

38. Boscolo PRS, Menossi M, Jorge RA: Aluminum induced oxidative stress in maize. Phytochemistry 2003, 62:181-189.

39. Rama DS, Yamamoto $Y$, Matsumoto $\mathrm{H}$ : An intracellular mechanism of aluminum tolerance associated with high antioxidant status in cultured tobacco cells. J Inorg Biochem 2003, 97:59-68.

40. Darkó É, Ambrusa H, Stefanovits-Bányai É, Fodo J, Bakos F, Barnabás B: Aluminum toxicity, Al tolerance and oxidative stress in an Al-sensitive 
wheat genotype and in Al-tolerant lines developed by in vitro microspore selection. Plant Sci 2004, 166:583-591.

41. Sharma P, Dubey RS: Involvement of oxidative stress and role of antioxidative defense system in growing rice seedlings exposed to toxic concentrations of aluminum. Plant Cell Rep 2007, 26:2027-2038.

42. Mossor-Pietraszewska T: Effect of aluminium on plant growth and metabolism. Acta Biochim Pol 2001, 48:673-686.

43. Özdemir F, Bor M, Demiral T, Türkan I: Effects of 24-epibrassinolide on seed germination, seedling growth, lipid peroxidation, proline content and antioxidative system of rice (Oryza sativa L.) under salinity stress. Plant Growth Regul 2004, 42:203-211.

44. Zhou N, Wei DP, Liu P, Cai MZ, Xu GD, Li ZG, Liang H: Effects of aluminum stress on themorphological and physiological characteristics in roots of two genotype rape seedlings. Chin J Oil Crop Sci 2008, 30:443-449.

45. Snowden KC, Richards KD, Gardner RC: Aluminum-induced genesinduction by toxic metals, low-calcium, and wounding and pattern of expression in root tips. Physiology 1995, 107:341-348.

46. Yang QS, Wang YQ, Zhang JJ, Shi WP, Qian CM, Peng XX: Identification of aluminum-responsive proteins in rice roots by a proteomic approach: Cysteine synthase as a key player in Al response. Proteomics 2007, 7:737-749.

47. He HY, He LF, Li XF, Gu MH: Effects of aluminum stress on reactive oxygen generation, lipid peroxidation and antioxidant enzyme activity in rye seedling. J Triticeae Crops 2005, 25:91-95.

48. Galvez L, Clark RB, Klepper LA, Hansen L: Organic acid and free proline accumulation and nitrate reductase activity in sorghum (Sorghum bicolor) genotypes differing in aluminum tolerance. Plant Soil 1991, 137:859-867.

49. Stephan UW, Prochazka Z: Physiological disorders of the nicotianamineauxotroph tomato mutant chloronerva at different levels of iron nutrition. I. Growth characteristics and physiological abnormalities as related to iron and nicotianamine Supply. Acta Bot Neerl 1989, 38:147-153.

50. Liu DH, Jiang WS: Effects of $\mathrm{Al}^{3+}$ on the nucleolus in root tip cells of Allium cepa. Hereditas 1991, 115:213-219.

51. Meng QM, Zou J, Zou JH, Jiang WS, Liu DH: Effect of $\mathrm{Cu}^{2+}$ concentration on growth, antioxidant enzyme activity and malindialdehyde content in garlic (Allium sativum L.). Acta Biol Cracov Bot 2007, 49:95-101.

52. Zhang HY, Jiang YN, He ZhY, Ma M: Cadmium accumulation and oxidative burst in garlic (Allium sativum). J Plant Physiol 2005, 162:977-984.

53. Bradford MM: A rapid and sensitive method for the quantitation of microgram quantities of protein utilizing the principle of proteindye binding. Anal Biochem 1976, 72:248-254.

doi:10.1186/1471-2229-10-225

Cite this article as: Qin et al: Effects of aluminum on nucleoli in root tip cells and selected physiological and biochemical characters in Allium cepa var. agrogarum L. BMC Plant Biology 2010 10:225.

\section{Submit your next manuscript to BioMed Central and take full advantage of:}

- Convenient online submission

- Thorough peer review

- No space constraints or color figure charges

- Immediate publication on acceptance

- Inclusion in PubMed, CAS, Scopus and Google Scholar

- Research which is freely available for redistribution

Submit your manuscript at www.biomedcentral.com/submit
Biomed Central 